\title{
Darnton, Robert. The case for books: past, present and future
}

André de Melo Araújo*

New York: Public Affairs, 2009. 240p.

Based on the correspondence between editors, philosophical writers and booksellers, as well as contracts granting the right to print and sell the Encyclopédie, Robert Darnton identifies in The Business of Enlightenment (1979) publisher conflicts and lucrative maneuvers in the lettered culture market in the 1700s. Thirty years after the first edition of this study, and taking into account the mechanisms of control for the production and circulation of printed knowledge, Darnton presents in The case for books (2009) challenging divergences and lucid identities between the (almost) two and a half centuries that separate pre-revolutionary France from the end of the first decade of the twenty-first century.

The thematic identity common to the two works is also present in the current reworking of the opening phrase of the 1979 text. In The Business of Enlightenment Darnton describes the results of his research as "a book about a book". In The Case for Books the historian reuses his consecrated formula by publishing "a book about books" (p.vii). In the plural the author inscribes the first divergent situation. In 1979 Darnton studied the history of the publication of a single book, the Encyclopédie. Thirty years later, and after having been director of Harvard University's network of libraries for a little over two years, Darnton identifies in the position he assumed in June 2007 "an opportunity to do something about the questions which... he had studied as historic phenomena" (p.ix).

These questions were preeminent: "as soon as I transferred to the new office, I discovered that Harvard Library was involved in secret conversations with Google about a project that took my breath away", Darnton reports. "Google planned to digitalize millions of books, starting with Harvard's collection and with those of another three university libraries, and to make the digital copies

* Kulturwissenschaftliches Institut Essen (KWI). Institute for Advanced Study in the Humanities, Goethestr. 3145128 Essen - Germany. andre_meloaraujo@yahoo.com.br 
available commercially..." (p.ix). The commercialization project for millions of books in a digital format reminded the historian of the traités which he had read to study the business of Enlightenment and to identify the necessary plural form of its new starting point. Based on the large number of books already digitalized, Darnton resolved to reflect principally on the role of research libraries and their possible paths in the era of knowledge stored in silicon memories.

The Case for Books is a collection of eleven texts published between 1982 and 2009, divided into three parts published in this order: future, present and past. In the book's title Darnton not only suggests the traditional form of storing books - on a book case -, but also echoes through the assonance between the words four and for the nucleus of the futuristic fantasy of Louis Sébastien Mercier, known since 1771 and according to which the voluminous collection of printed knowledge will be a thing of the past. The truth of the future will fit "into the four bookcases" (p.44). Darnton, thus, starts with the future of the past to sound a warning about the present of the future: "We could have created a digital national library - the twenty-first century equivalent of the Library of Alexandria. It is too late. We have not only failed to conceive this possibility, but, which is even worse, we are allowing that a question of public policy - the control of access to information - is determined by private lawsuit" (p.17). I summarize below Darnton's three central concerns about the future.

1) In studying the eighteenth century culture of letters, the historian locates, starting with the France case, a project for the opening and spreading of knowledge which in principle was universalist. Nevertheless, the enlightenment project paradoxically restricted its universalism to the economically favored population. Darnton's first alert about the future is about paid access to knowledge networks controlled in turn by a private monopoly. Darnton really talks about Google and archive digitalization projects with very enthusiastically. However, his concern is with what he calls "monopolistic tendencies" (p.33).

2) The author insists that public institutions should have a more active presence in policy decisions about access to knowledge: "Yes, we have to digitalize. But more importantly: we have to democratize. We have to open access to our cultural heritage. How? Rewriting the rules of the game, subordinating private interests to the public good..." (p.13). In this way Darnton proposes the union of libraries in the future in the name of a project of a large public digital library (p.57): "Openness, free access, is the guiding principle that we should seek to follow to adapt libraries to the conditions of the twenty-first century" (p.50). 
3) By emphasizing the high price that libraries currently pay to keep their collections of periodicals up to date, Darnton is concerned with the commitment of research library budgets to the high charges to digital collections, originally based on public collections. As a consequence the libraries of the future will have to acquire less books (p.18-19)!

Other structural problems arise out these three central concerns. The instability of information, as defined by Darnton (p.23), requires the possibility of exploring minimal variations in the world of ideas: various copies of the same title - something which can be left aside to allow the digital world be resumed in four shelves - can present revealing dissonances in lettered culture (p.29-31). A historian by profession, the new librarian distrusts the efficiency of the preservation system of digital: temporary materiality - or almost 'immateriality' - of books born in the digital format can be dissipated in the cybernetic space (p.37). Darnton also expands the warning by mentioning the fragility of the registration of communications in the contemporary world (p.53). Its tonic principally falls on the need to discuss public policies for the preservation of collections and the control of the channels for the dissemination of knowledge. This is the reason for which the responsibility of libraries increases in the digital era, not only to keep in mind the ideal of free access to sources of research, but also because they see themselves as responsible for preserving the past of the future. The assumption of all historians is well known: if the present does not leave traces for the future, it can never be the past.

Some of Darnton's concerns about the future are repeated in the second part of the text, in other words in the present. The repetitions of the arguments, though not of the actual examples, marks the reading of this collection of texts which seeks to destroy the myth that the electronic future puts at risk the tradition of printed books (p.67). In order to explore how ink and paper coexist with electronic information technology in the contemporary world (p.77), The Case for Books was launched simultaneously as an e-book and in the traditional format of a printed codex.

In the final chapter, in other words in the part most directly related to the past, Darnton republishes his classic 1982 study of the history of books, available to the Brazilian public for two decades in $O$ beijo de Lamourette. In this text he discusses how the forms of transport and communication decisively influenced the history of literature (p.199). In his recent revision of the 1982 article, Darnton insists on the material character of the object called a book, ${ }^{1}$ and this insistence is again present in The Case for Books. Familiarized with the world 
in which news was seen as being tied to a paper format (p.109), Darnton highlights the importance to the historian of material contact with research sources: the color and size of pages, (p.125), even the experience of turning them pages one by one is part of the study of reading practices.

In the same way that Darnton insists on looking for a conciliatory outcome between printed and electronic formats for the past, for the present and the future of books - giving proof that the historian is not just concerned with the past -, I also prefer here to sketch out a conciliatory path between the two professional activities carried out by Robert Darnton, historian of the French Enlightenment and director of Harvard University's library network. I start from the core cause of the divergences - between the past and the future which challenge the present and through which Darnton seeks to lucidly indicate in The Case for Books, some identities.

The digitalization - and commercialization - project of millions of books, as Darnton discovered in his new office in Harvard, brings to mind the Enlightenment economic and epistemological model, to which The Case for Books offers a skeptical response and a challenge. In the epistemological sphere the Enlightenment model seeks to order and tie together the knowledge of mankind - as D'Alembert proposed in his preliminary discourse in the Encyclopédie in 1751 - or also to bring together the knowledge disseminated around the world, as Diderot suggested in the fifth volume of the same work. Darnton's skepticism comes into action by highlighting gaps and fragilities in projects with a supposedly totalizing nature. In the case of digital collections incomplete pages and the potential absence of variants are clear indications of this fragility.

From the economic point of view the promise of access to compact volumes of written culture is shown again to be a great business. However, what the challenge proposed by Darnton seeks to renew in the twentieth-first century is the terms of the 1700s utopia, according to which the large public digital library will ensure universal access to knowledge. In other words, on the one hand the reflections published in The Case for Books repeat the criticism of the Enlightenment project by lucidly identifying similarities between the market interests of large business of the past and the future, as well as between forms of privilege of access to written culture. On the other hand Darnton seeks to expand the same project which he had studied as a historic phenomenon, to the extent that it relies on the redefinition of mechanisms of universal access 
to lettered knowledge. In The Case for Books the future of the present is a bet on the failure of the universalism of the past.

\section{NOTES}

${ }^{1}$ Cf. Darnton, Robert. "What is the history of books?" Revisited. Modern Intellectual History, Cambridge: Cambridge University Press, v.4, Issue 3, p.495-508, 2007.

Submitted in February 2010. Approved in July 2010. 


\title{
Araujo, Valdei Lopes de. A experiência do tempo: conceitos e narrativas na formação nacional brasileira (1813-1845)
}

\author{
Pedro Spinola Pereira Caldas*
}

São Paulo: Hucitec, 2008. 204p.

Great advantage should be taken of the publication of $A$ Experiência do Tempo by Valdei Lopes de Araujo. It is a rich book, worthy to find a place on the bookshelves of those interested in the political and intellectual history of nineteenth century Brazil, but also in the libraries of those who study the history of historiography and - why not? - the philosophy of history. Even better it can awaken in those of an empirical vocation interest in more abstract questions, as well as showing more speculative and reflexive minds that concepts can find correspondence in mutual historical reality.

Valdei Lopes de Araujo is a professor in the Universidade Federal de Ouro Preto (UFOP), where he is part of the History of Historiography and Modernity Study Group (NEHM). The book is the fruit of his doctoral dissertation in the Post-Graduate Program in the Social History of Culture in PUC-Rio, the result of research supervised by Luiz Costa Lima. The refined approach of Valdei Araujo can be explained, without seeking to diminish the originality of the work, in part by the supervision of an intellectual who always stimulated theoretical reflection and who was one of those responsible for the diffusion of literary hermeneutics in Brazil, and which results in the great contribution of Valdei Araujo's book to theoretical and historiographical debate. Its merit, thus, consists of the sophisticated incorporation of theoretical discussion developed in Germany in the second half of the twentieth century, especially among the heirs and critics of the philosophical hermeneutics of Hans-Georg Gadamer, an author who influenced both the historian Reinhart Koselleck and the important theorist and literary critic Hans-Ulrich Gumbrecht. The influence of Koselleck and Gumbrecht can be felt in Valdei Araujo's text: from the first comes a concern with conceptual history, a genre in which the author

\footnotetext{
* Associate Professor II, Institute of History, Universidade Federal de Uberlândia, Santa Mônica Campus. Av. João Naves de Ávila, 2121, Bloco H, sala 1H42. 38400-902. Uberlândia - MG Brazil.pedro.caldas@gmail.com
} 
comes out really well, giving a good example of how concepts are not polished reflexes of historical life, but the actual way the latter becomes intelligible. Thus, the concept is the place of experience and not the distanced and disinterested cognition of dilettante intellectuals. Nothing better than a good work in the area of the history of concepts to give students of Brazilian history and historiography the chance to break away from the homogenous image of the rhetorical and unoccupied Brazilian intellectual, who is only concerned with the world of letters for distraction and ornamentation. But the concept - and here the influence of Gumbrecht can be perceived - is also the fruit of a radical and circumstantially located historical presence. The book fortunately appropriates theoretical texts such as those of Koselleck and Gumbrecht without at any moment turning the author's research into a list of imported concepts, an application that merely confirms what was already known. As a result although the work deals with sources that have mostly been analyzed by other historians, the way they are used is both original and creative.

The book starts with a fundamental question in relation to the independence of Brazil and what this categorically represents as a modern experience. As Valdei Araujo states in his closing considerations: "The relationship with time and with the past was still conditioned, on the one hand by classical elements of imitation and on the other by a general understanding of the universe as the repetition of eternal laws and cyclical events" (p.185).

The first part of the A Experiência do Tempo, called 'The History of the System', basically describes and analyzes the somewhat tragic trajectory of José Bonifácio de Andrada e Silva, which, taking as a base a cyclical vision of history, conceives the meaning of history in Brazil through regeneration. Regeneration is only possible if it is understood as the stage that follows decadence, a fundamental term for the morphological comprehension of the natural sciences. Incidentally, it is instigating to perceive the similarity of the Brazilian intellectual debate about modernization and the discussion held in German space in the last quarter of the eighteenth century, as shown by the research of Peter Hans Reill. ${ }^{1}$ However, 'regeneration' for Bonifácio implies the recovery of the essence of the Portuguese being, which even when transplanted to Brazil does not signify a return. To use the terms of the author, by 'mirroring' the history of Portugal, the history of Brazil opens the possibility in its search for awareness that there exists "another history that can no longer be that of Portugal" (p.63). This is the dialectic delineated by Valdei Araujo, that of 'time as repetition' (the title of the first chapter) and 'time as a problem' (the title of the second chapter). The attempt to achieve a natural surpassing of decadence thus opens 
a crack for the modern project. After all, regeneration occurs in pure, virgin nature, fully visible in its creative principles, whose potentiality has been molded by science. ${ }^{2}$ The dilemma of the singularity of Brazilian history, since Bonifácio according to the author, is closely unfolded in the examination of the possibility of the historical existence of Brazilian literature and language, which should be constructed taking as a basis the classical Greek-Latin axis, but without making this base a model to be merely copied.

The second part of the book (The System of History), which includes an excursus and two addition chapters, deals with the way that Brazilian intellectuals faced the discomfort generated by the unavoidable necessity to affirm national singularity. Discomfort? Necessity? Yes. The author states this very precisely: "The available theories that can explain the creation of new forms, whether animal or political, are often based on the idea of degeneration" (p.126), and concludes by demonstrating the dimension of the problem that if the organicist model was true, "change could only be understood as improvement, regeneration or degeneration. Would this not also be valid for nations? How to understand the emergence of a new nation?" (p.126).

Valdei Araujo then presents the efforts of the intellectuals involved with Nitheroy journal (such as Domingos José Gonçalves de Magalhães) and the foundation of the IHGB. While in the former it is easier to perceive the romantic tonality with which the national singularity is colored in the phase of affirmation (but in which history belonged to a wide-ranging group of 'lettered' persons), in the founding document of IHGB, dated 16 August 1838, the presence of striking traits can be perceived, which - as the author importantly notes - Arnaldo Momigliano considered to be fundamental for the characterization of modern historiography, in other words the conjunction of the antiquarian and erudite tradition, the concern with the philosophical meaning of history, and finally narrative. For Valdei Araujo the first trait is much more visible that the other two, with the third one being especially discreet.

Another facet of modernity emphasized by the author, as important as the establishment of the foundations of historical research (and arising out of it), resides in the opening of the possibility of experiences in the place of imitation. This is not the recapitulation of an already existing, registered, taught and known example, but above all the expression of the individuality of an epoch. The fact is unthinkable within cosmological or exemplar models, but it becomes 
cognizable in its assimilation by antiquarian and erudite research in the scope of the attempt to affirm national singularity.

Singularity in any form operates an interest semantic transformation: degeneration leaves room for consciousness of finitude, for consciousness of a typically modern experience - the sensation of the transitoriness of all experiences. IHGB's initial project, as shown well by Valdei Araujo, was marked by an essential ambiguity: distant from the organicism which animated José Bonifácio, the lettered world that revolved around the institute did not breathe the air of evolutionary thought, at that moment the only thing capable of, to draw on an expression of Henry James, being the thread capable of stringing all the pearls. How to differentiate the epochs of the history of Brazil? How to organize the facts?

Valdei Araujo's book plays an important role in the current environment of theoretical and historiographical discussion, marked by the clash between the almost cynical skepticism of the so-called 'post-moderns' and rationalists. Experiência do Tempo shows the Brazilian historiography made a fundamental jump at of moment of crisis of orientation - to use a term of Jörn Rüsen. Therefore, there is no problem in writing history in times of uncertainty. In some way it has always like this and the challenge has always been responded to, albeit in very different ways by historians.

\section{NOTES}

${ }^{1}$ Cf. Reill, Peter Hans. Vitalizing nature in the Enlightenment. Berkeley: University of California Press, 2005; Die Historisierung von Natur und Mensch. Der Zusammenhang von Naturwissenschaften und historischem Denken im Entstehungsprozess der modernen Naturwissenschaften. In: Küttler, Wolfgang; Rüsen, Jörn; Schulin, Ernst. Geschichtsdiskurs Band 2: Anfänge modernen historischen Denkens. Frankfurt am Main: Fischer, 1994.

${ }^{2}$ In relation to this please allow me to make a comparison. José Bonifácio reminds us much of the Goethe who travelled to Italy. In the peninsula he found juvenile serenity and the naturalness whose absence he has so resented in Weimar, where he was already an important intellectual name, suffocated by courtly formalities. It is worth remembering that both - Bonifácio and Goethe - dedicated themselves widely to natural science. For a vision of conception of nature in Goethe, see Molder, Maria Filomena. O Pensamento morfológico de Goethe. Lisboa: Imprensa Nacional-Casa da Moeda, 1995.

Submitted in November 2008. Approved in July 2010. 


\section{Almeida, Maria Regina Celestino de. os índios na história do Brasil}

Elisa Frühauf Garcia*

Rio de Janeiro: Ed. FGV, 2010. 168p.

Until very recently Indians were practically absent subjects in our historiography. Relegated to the condition of passive victims of processes of conquest and colonization, their inexorable destination was to disappear as the society around them expanded. In the last two decades, however, significant theoretical and methodological changes, associated with meticulous empirical research have led to the emergence of a new perspective on native populations.

The trajectory of the insertion of Indians in our historiography, covering conceptual changes and advances made in recent research, have been very well summarized by Maria Regina Celestino de Almeida in Os Índios na História do Brasil. Its publication in the History series of the FVG Bolso [pocket books] Collection will without a doubt be of great value to those interested in the question. It also fulfills its function of disseminating knowledge produced in academia. In addition, the launch of the book takes place at an opportune moment. In 2008 the federal government enacted Law 11645, which makes the teaching of indigenous history obligatory in public and private primary and secondary schools. Many teachers are facing difficulties fulfilling this requirement, since it has not yet been properly inserted in undergraduate history courses in Brazil.

The author initiates the book presenting the change in the place occupied by Indians in the history of Brazil, who in her words have moved from 'backstage' to the 'stage' itself. Debating in general terms the principal theoretical and methodological modifications that have allowed this change, she shows how the new perspective about the meanings of culture and identity were fundamental for an alteration in the paradigm of Indian actions in different

\footnotetext{
* Associate Professor, Universidade Federal Fluminense. Center of General Studies, Institute of Human Sciences and Philosophy, Gragoatá campus. Block O, 5th floor, Gragoatá. 24210-350 Niterói - RJ - Brazil. elisafg@terra.com.br
} 
scenarios. As shown in a clear and concise form in the text, the approximation between history and anthropology, anchored in the dialogue between professionals in these areas, allowed the old notions of culture and identity, previously perceived as "fixed and immutable" (p.21), to be considered as the fruit of historic processes, resulting from the dynamic interactions of different agents involved in specific situations.

Articulating theoretical and methodological questions in recent research on the issue, the author looks at fundamental aspects for the understanding of the place of Indians in Brazilian history, starting with a discussion about the dynamics of wars. Without denying the importance of war for native groups, as demonstrated by authors such as Florestan Fernandes, Regina Celestino emphasizes the impossibility of analyzing them without reference to their context, since after the first contacts and the disputes for American territory, indigenous wars converged with colonials wars. Associated with wars and the construction of colonial society, the authors also deals with the difficult question of the formation of ethnicities, one of the most important current discussions about indigenous peoples. Research about the emergence and operationality of the ethnonyms developed in various regions in the Americas, including Brazil, demonstrate how many ethnicities, previously believed to have existed before contact with Europeans, actually emerged from the process of conquest and different forms of insertion of Indians in colonial society. To exemplify this question the author uses as a database her doctoral thesis, showing how the Temininós, fundamental allies of the Portuguese in Guanabara, were probably no more than a dissident faction of the Tamoios consolidated during the process of conquest. ${ }^{1}$

In analyzing the formation of ethnonyms, the author emphasizes how they were interlinked with the domination of indigenous peoples by the colonial state. The creation and crystallization of ethnonyms and the rigid separation of Indians between allies and enemies was a form of classifying the native population and enabling the colonial project through their allocation to determined places in the social hierarchy. Regina Celestino, however, demonstrates very well that this process was more complex, since she also deals with the mechanisms through which the Indians appropriated these categories, using them as a basis to prepare their own strategies to interact with colonial society. After all, as highlighted by John Monteiro, "the tendency to define ethnic groups in fixed categories served not only as an instrument of domination, but also as a parameter for the ethnic survival of indigenous group, supporting a variety of strategies". 2 
One of the spaces par excellence for the insertion of Indians in colonial society, and consequently, the redefinition of their identities and cultures were the aldeamentos (settlements), analyzed with authority by the author in chapter four. Until very recently our historiography looked at the aldeamentos from the viewpoint of the colonial state, the inhabitants, or the missionaries. They were then defined as spaces for the grouping of Indians from various origins to serve colonial purposes, - allowing both the concentration of the available labor for use in various activities and the implementation of the native catechization project. From this perspective the Indians were always the object of different policies and disputes between determined agents, never active subjects in the construction of space in the aldeamentos. For the author, however, they should also be considered from the point of view of native motivations. Recent research allows us to confirm their interest in these establishments, since they "participated in their construction and were active subjects in the processes of resocialization and catechism" that occurred in those spaces (p.72).

Another important contemporary discussion dealt with in the book, especially in chapters four and five, is the relationship of Indians with colonial directives, articulating with indigenous policies. Once again Regina Celestino redimensions certain historiographic assumptions. Generally speaking, the indigenist policy of the Portuguese crown was presented as inoperative to the extent that it did not valorize colonial practices, especially in relation to the condition of legal liberty granted to the majority of Indians, threatened by the strategies of colonists interested in this labor. However, as Thompson has highlighted rather than just being a mere instrument of domination, legislation is also configured as a field of struggle. ${ }^{3}$ In this way, like other historic subjects the Indians, despite remaining in a subaltern position, learned to use this for their own interests. As the author shows very well, although colonial indigenist legislation was applied in accordance with conflicts and negotiations involving various agents (principally missionaries, royal employees and colonists), it is essential to consider the role of Indians in this process. In this discussion chapter five, about the implementation of Pombaline policies, acquires fundamental important. The general line of these policies was aimed at the extinction of aldeamento Indians, promoting their dilution in the population as a whole. In the analysis of this legislation, one of the areas most researched by historians of this theme, it is evident that constant negotiation with Indians was one of the main marks in the construction and maintenance of colonial society. 
In the final chapter the author looks at the nineteenth century, focusing on the differences between imperial policies in relation to Indians 'of the present' and the place they were given in the national identity then being constructed. The Indians of the present, especially those who lived in villages founded during the colonial period, were to be rapidly integrated in the general population, in accordance with what Pombal had previously ordered. Those Indians not yet fully inserted in colonial society, commonly called 'savages', were to be settled, also with the objective of preparing their dilution in the population, and were implacably combated if they did not accept the settlements and resisted the expansion of occupation. The Empire projected a homogenous population, without space for Indians to remain as a differentiated group. However, an important place was reserved for natives in the past of the young nation. Despite significant divergences, among the intellectuals involved in the construction of national identity there prevailed a proposal attributing Indians an important role in the founding of Brazil, symbolizing their union with the Portuguese.

By looking at the place of Indians in the history of Brazil, including different scenarios, interests and agents, Regina Celestino offers readers an important initiation in the question. After reading her book, it is evident that it does not just involve perceiving the specific histories of different native groups, which was certainly importantly, but also considers them as fundamental agents in the process of the construction of colonial and post-colonial society. Despite facing extremely difficult situations and a series of legal and social reactions, they helped to mark the limits and possibilities of those societies.

\section{NOTES}

${ }^{1}$ Almeida, Maria Regina Celestino de. Metamorfoses indígenas: identidade e cultura nas aldeias coloniais do Rio de Janeiro. Rio de Janeiro: Arquivo Nacional, 2003.

${ }^{2}$ Monteiro, John. Tupis, tapuias e historiadores: estudos de história indígena e do indigenismo. Dissertation (Associate Professorship in Anthropology) - Universidade Estadual de Campinas. Campinas (SP), 2001, p.58.

${ }^{3}$ Thompson, Edward P. Senhores e caçadores: a origem da lei negra. Rio de Janeiro: Paz e Terra, 1987, p.358.

Submitted in August 2010. Approved in August 2010. 